\title{
Review of MicroRNA Deregulation in Oral Cancer. Part I
}

\author{
Antonia Kolokythas ${ }^{1,2,3}$, Michael Miloro ${ }^{1}$, Xiaofeng Zhou ${ }^{2,4}$ \\ ${ }^{1}$ Department of Oral and Maxillofacial Surgery, University of Illinois at Chicago, USA. \\ ${ }^{2}$ Center of Molecular Biology and Oral Diseases, College of Dentistry, University of Illinois at Chicago, USA. \\ ${ }^{3}$ Cancer Center, University of Illinois at Chicago, USA. \\ ${ }^{4}$ Department of Periodontics, College of Dentistry, University of Illinois at Chicago, USA.
}

\author{
Corresponding Author: \\ Antonia Kolokythas \\ Assistant Professor and Director of Research \\ Department of Oral and Maxillofacial Surgery \\ University of Illinois at Chicago \\ 801 S. Paulina Street, MC 835, Chicago, Illinois, 60612-7210 \\ USA \\ Phone: 312-996-1052 \\ Fax: 312-996-5987 \\ E-mail: ga1@uic.edu
}

\begin{abstract}
Objectives: Oral cancer is the sixth most common malignancy worldwide. Cancer development and progression requires inactivation of tumour suppressor genes and activation of proto-oncogenes. Expression of these genes is in part dependant on RNA and microRNA based mechanisms. MicroRNAs are essential regulators of diverse cellular processes including proliferation, differentiation, apoptosis, survival, motility, invasion and morphogenesis. Several microRNAs have been found to be aberrantly expressed in various cancers including oral cancer. The purpose of this article was to review the literature related to microRNA deregulation in the head and neck/oral cavity cancers.

Material and Methods: A comprehensive review of the available literature from 2000 to 2011 relevant to microRNA deregulation in oral cancer was undertaken using PubMed, Medline, Scholar Google and Scopus. Keywords for the search were: microRNA and oral cancer, microRNA and squamous cell carcinoma, microRNA deregulation. Only full length articles in the English language were included. Strengths and limitations of each study are presented in this review.

Results: Several studies were identified that investigated microRNA alternations in the head and neck/oral cavity cancers. Significant progress has been made in identification of microRNA deregulation in these cancers. It has been evident that several microRNAs were found to be deregulated specifically in oral cavity cancers. Among these, several microRNAs have been functionally validated and their potential target genes have been identified.

Conclusions: These findings on microRNA deregulation in cancer further enhance our understanding of the disease progression, response to treatment and may assist with future development of targeted therapy.
\end{abstract}

Keywords: oral cancer; oral neoplasms; head and neck cancer; head and neck neoplasms; microRNA; review.

\author{
Accepted for publication: 13 April 2010 \\ To cite this article: \\ Kolokythas A, Miloro M, Zhou X. Review of MicroRNA Deregulation in Oral Cancer. Part I. \\ J Oral Maxillofac Res 2011 (Apr-Jun);2(2):e1 \\ URL: http://www.ejomr.org/JOMR/archives/2011/2/e1/v2n2e1ht.pdf \\ doi: $10.5037 /$ jomr.2011.2201
}




\section{INTRODUCTION}

Cancer of the oral cavity and oropharynx (OCC) remains among the top ten malignancies in the United States and worldwide. These cancers account for $4 \%$ of malignancies in men and $2 \%$ of malignancies in women. In the United States despite current advances in treatment one human life every hour is lost to this cancer. According to American Cancer Society while overall new head and neck/oral cavity cancer cases increased about $8 \%$ during the past 5 years, the new cases for oral cancer increased about $21 \%$ (Table 1). In the 2010 cancer statistics published by the American Cancer Society there are 36,540 estimated new cases of oral cavity/oropharynx cancers and 7,880 deaths from these cancers [1]. An alarming fact is the recent increase of these cancers worldwide among younger individuals often without risk factors or not engaged in known high risk social habits such as smoking and alcohol consumption [2, $\underline{3}]$. Despite current advances in treatment the reported overall five year disease free survival worldwide remains largely unchanged over the past several decades for all races (range between $45-65 \%$ ) [1, $\underline{4-7}]$. Failure to cure OCC despite optimal treatment is a reality and these cancers remain an undertreated and poorly understood disease process that represents a major health problem. Improvement of survival and treatment outcomes require a better understanding of the disease progression so that these cancers can be diagnosed early and most importantly targeted therapy can be initiated accordingly.

The initiation and progression of OCC is a highly complex multistep process that entails progressive acquisition of genetic and epigenetic alterations and dynamic changes in the genome. Thus far, the majority of the studies on the cancer genome have focused primarily on the protein coding genes and their alterations. The impact of non coding sequences

Table 1. The changes of head and neck/oral cavity cancer (HNOCC) incidence and death for the past 5 years

\begin{tabular}{ccccc}
\hline \multirow{2}{*}{ Year } & \multicolumn{2}{c}{ New cases } & \multicolumn{2}{c}{ Deaths } \\
\cline { 2 - 5 } & All cancers & HNOCC & All cancers & HNOCC \\
\hline 2005 & 1.372 .91 & 29.37 & 570.28 & 7.32 \\
2006 & 1.399 .79 & 30.99 & 564.83 & 7.43 \\
2007 & 1.444 .92 & 34.36 & 559.65 & 7.55 \\
2008 & 1.437 .18 & 35.31 & 565.65 & 7.59 \\
2009 & 1.479 .35 & 35.72 & 562.34 & 7.6 \\
\hline Total (2005 - 2009) & 7.134 .15 & 165.75 & 2.822 .75 & 37.49 \\
\hline 5 year increase & 106.44 & 6.35 & -7.94 & 280 \\
\% increase & $7.8 \%$ & $21.6 \%$ & $-1.4 \%$ & $3.8 \%$ \\
\hline
\end{tabular}

in disease initiation and progression including cancers remain largely unknown [ㅇ-10]. Although at least $65 \%$ of the genome is transcribed, protein-coding transcripts are derived from less than $2 \%$ of the human genome [11]. The mammalian genome harbours genes that although they do not encode proteins have an important role in normal cell development and disease process and these non protein transcripts may make up at least half of all transcripts in mammals [12].

RNA interference (RNAi) in a variety of organisms is a known process of sequence specific post-transcriptional gene silencing initiated by double-stranded RNA $[13,14]$. RNAi was first discovered in 1998 in the neomatome Ceanorhabditis elegans, but is conserved in variety of organisms and is considered a major regulatory mechanism in eukaryotic gene expression [15]. In mammalian cells RNAi regulation of endogenous genes occurs by the production of short double-stranded RNA molecules or microRNA. MicroRNAs mediate gene expression at the post-transcriptional level by degrading or repressing target messenger RNAs (mRNA) or by translational inhibition of target genes. Since the initial discovery of the founding members of the microRNA family, lin-4 and let-7 several hundreds have been identified in all species by combination of molecular cloning and bioinformatics. It is now estimated that 1,000 microRNAs exist in the human genome [16-24]. The purpose of this article was to review the literature related to microRNA deregulation in the head and neck/ oral cavity cancers.

\section{MATERIAL AND METHODS}

A comprehensive review of the available literature from 2000 to 2011 relevant to microRNA deregulation in oral cancer was undertaken using PubMed, Medline, Scholar Google and Scopus. Keywords for the search were: microRNA and oral cancer, microRNA and squamous cell carcinoma, microRNA deregulation. Only full length articles in the English language were included. Strengths and limitations of each study are presented in this review.

\section{MicroRNA formation}

MicroRNAs are encoded by genes located either in non coding regions or in introns of protein coding genes and require a complex set of proteins for their formation $[\underline{25,26]}$. Thus primary microRNA transcription may be by an independent promoter or by a promoter of the proximal coding gene. Most microRNAs are transcribed by the RNA 
polymerase II to primary microRNAs that are longer nucleotide sequences (hundreds to even thousands of nucleotides). Approximately 20\% are transcribed by the RNA polymerase III into primary mircoRNAs. These are then spliced and capped with a 5' 7-methylguanosine cap $\left({ }^{\mathrm{m} 7} \mathrm{G}\right)$ and poly-adenylated at the 3 ' end. This is a process similar to protein-coding messenger RNA process. The primary microRNAs form specific hairpin-shaped stem loop secondary structures prior to be processed by a microprocessor complex (500 - $650 \mathrm{kDa})$ into pre-microRNAs. The complex, consistent of Drosha (RNase III endonuclease) and the essential cofactor DGCR8/Pasha, processes the primary mircoRNAs into 60 - to 70 - nucleotide long pre-microRNA with a 5' phosphate and a 3' nucleotide overhang. Exportin 5, a member of the Ran transport receptor family, transports the pre-microRNA to the cytoplasm. In the cytoplasm further processing to short double strand microRNA/microRNA* occurs by Dicer, a second RNase III endonuclease, prior to unwind of the duplex by a helicase to reveal the final mature microRNA and microRNA*, which is quickly degraded [27]. The average ratio of microRNA to microRNA* is approximately 100 to 1 but can be much lower in cases of both strands are functional and incorporated into RISC that is shown to occur [27-29]. The mature microRNA product is noncoding, regulatory RNA molecules 22 nucleotides long that can be asymmetrically incorporated into RNA-induced silencing complexes (RISC) that are then guided to the target mRNA [9, 30-32].

\section{MicroRNA physiologic functions}

It is well established that microRNAs are involved in diverse physiologic processes [33-36]. Studies with mouse embryos and zebra fish Dicer-null phenotype revealed that microRNA pathway is not generally required for cellular viability but plays a prominent role in various tissue specific cell types and morphogenesis of embryonic structures. Such examples are impact of microRNAs on T-cell development/differentiation as well as morphogenesis of lung, limp and skin as well as maintenance of hair follicles [37-42]. The ability of microRNAs to dramatically influence tissue(s) specific generation and behaviour is another important function of these molecules. This is demonstrated in studies on microRNA-181, the first mammalian microRNA to be carefully studied as well as microR $A A-1$ the most highly conserved microRNA. MicroRNA-181's ectopic expression in hematopoietic progenitor cells skews their differentiation towards the B-cell lineage while the same microRNA is up-regulated during differentiation and regeneration of muscle cells $[\underline{43}, \underline{44}]$. MicroRNA-1 conversely demonstrates skeletal and cardiac muscle specific expression and is shown to be critical in development of normal muscle $[\underline{21}, \underline{45}, \underline{46}]$. Over-expression or inhibition of microRNA-1 promotes or inhibits respectively mammalian muscle cell

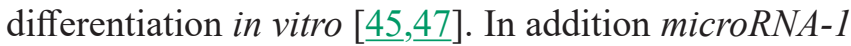
has been shown to also play an important role in muscle physiology [45, $\underline{48-50]}$. The involvement of microRNA-138, that is also frequently deregulated in OSCC as will be discussed later, in differentiation of human adipose tissue derived mesenchymal stem cells is another recent discovery. During adipose differentiation microRNA-138 was found to be significantly downregulated, while it's over expression effectively reduced lipid droplets accumulation and inhibit expression of key adipogenic transcription factors. These findings could provide insights into the pathogenesis of a number of diseases such as obesity and diabetes and potentially broaden the spectrum of stem cell based therapy for these conditions [51]. These findings stress the fact that a single microRNA can participate and impact on distinct pathways in various tissues and have the ability to influence the generation and behaviour of tissuespecific cell types.

It is now accepted that microRNAs are important in establishing and/or maintaining gene expression patterns that are characteristic of specific tissues [52]. It has been shown that many microRNAs and their predicted target are reciprocally expressed $[\underline{53}, \underline{54}]$. Lastly, several cell-autonomous functions, not related to development or differentiation, have been shown to be controlled by microRNAs. Such examples include insulin regulation and specific expression of microRNA-375 in pancreatic islet beta cells and cholesterol homeostasis by liver specific microRNA-122. The brain and nervous system is perhaps the most extensively studied in reference to microRNA and regulation of function in vertebras. For example neuronal differentiation and synaptic function have been found to be controlled by microRNA-9 and microRNA-124 while neuronal outgrowth and dendritic morphogenesis by microRNA-134, microRNA-132. Another interesting implication of microRNAs in function has originated from identification of microRNA-138 involvement in dendritic spine size morphogenesis, via synaptic protein synthesis, that is associated with formation of long lasting memories [55-61]. In addition to key roles in the nervous system development and function micrRNA-138 has been implicated in cardiac patterning-compartmentalization during embryonic development [62]. It is evident from the current and growing literature that microRNAs have global participation and impact on normal physiologic processes. A logical extension to this conclusion is that any alteration or abnormalities in 
their function would influence disease phenotypes in all organisms $[\underline{44}, \underline{63}, \underline{64}]$. Additional information on microRNA functions and microRNAs in physiology and disease process can be found in the excellent reviews on the subject by Bushati et al. and Chang et al. $[\underline{63}, \underline{64}]$.

\section{MicroRNA and cancer of the oral cavity and oropharynx (OCC)}

Since their initial discovery the microRNA gene family is continuously growing with novel members discovered in association with several disease processing. Once sufficient information on microRNA was made available several commercially available microRNA array platforms were developed and subsequently employed successfully in identification of microRNA deregulation in head and neck/oral cancers. The currently available technology has necessitated and facilitated the establishment of several online databases for tracking and to accommodate this constantly growing list. Identification of potentially "cancerous" microRNAs has been based mainly in their differential expression in cancers compared with controls. Interestingly enough studies have suggested that microRNA signatures could be used to classify malignancy based on their tissue of origin $[\underline{65}, \underline{66}]$.

Jiang et al. in 2005 employed real time quantitative PCR - based methods to successfully identify microRNA deregulations in thirty two cancer cell lines including five from the head and neck/oral cavity [67] Clustering analysis based on the expression values of these microRNA precursors enabled most of the cancer cell lines to be clustered based on the tissue of origin [67]. This is suggestive of the presence of microRNA expression signatures/profiles of cancers based on the specific tissue of origin. This is in line with the previously discussed identification of organ/ tissue specific microRNAs and their link to physiologic function and disease process $[43,45,48, \underline{4}, 55,58,60,64]$. Tran et al. in 2007 using microarray profiled for 261 microRNAs using 9 cell lines (from hypopharynx, base of tongue, oral tongue, tonsil and larynx) identified 33 upregulated and 22 down-regulated microRNAs, several of which are known to be involved in carcinogenesis [68]. This study remains the first to provide such a large genome-wide survey of mature microRNA in head and neck cancer.

Hebert et al. in 2007 studied microRNA expression patterns in squamous cell cancer cells from the head and neck that were cultured under hypoxia conditions [69]. Cells from 3 cell lines were grown under normoxic conditions or hypoxia ( $5 \%$ and $1 \%$ oxygen) and profiling was carried using Human_V7.1C_051017 microRNA array (LC Sciences). Interestingly twenty microRNAs were up-regulated including microRNA-572, microRNA-214, microRNA-563, microRNA-15a, microRNA-200a, microRNA-7, let-7a, let-7g, let-7i. Among the 16 down-regulated microRNAs under these conditions were microRNA-122a, microRNA-565, microRNA-195, microRNA-30e-5p, microRNA-374, microRNA-19a, microRNA-22. Hypoxia is important in progression and treatment as it has been implicated in development of chemoresistance in head and neck/oral cancers. The results reflected profiling differences in the cancer cell lines and no nonmalignant controls were used, but the study associates hypoxia conditions with microRNA deregulation and potential development of resistance to chemotherapy. Identification of microRNA alterations in these conditions could facilitate our understanding of this adaptation by the cancer cell and guide targeted therapy [69].

An array containing 646 mature and pre-microRNA, GenoExplorerTM from Genosensor Corporation (Tempe, AZ, USA) was used to screen for altered microRNA expression by Chang et al. in 2008 [10]. The study, that included head and neck squamous cell carcinoma cell lines, primary tissue samples and normal tissue controls, identified eight microRNAs to be upregulated and one down-regulated in the cancer samples compared to controls. MicroRNA-21, microRNA-18, microRNA-19, microRNA-29c, microRNA-142, microRNA-3p, microRNA-155, microRNA-146b and let-7 that known to be involved in tumorigenesis were in the unregulated group [10].

Profiling of squamous cell carcinoma of the tongue was carried in two studies by Wong et al. in 2008 [70,71]. Laser dissected cells from four tongue cancers and paired normal tissue were used to examine expression levels of 156 human mature microRNAs using qRTPCR (Tan Man microRNA Assays; Human Panel). Twenty four microRNAs, including microRNA-184 and microRNA-21, were up-regulated and 13 were down-regulated, including microRNA-100, microRNA 125, microRNA-133a and microRNA-133b. A 3-fold expression difference was the cut-off level used [무, 71$]$. In their attempt to identify a microRNA signature specific to oral cavity squamous cell carcinoma, Kozaki et al. in 2008 examined the expression profile of 148 microRNAs in 18 cancer cell lines and immortalized oral keratinocyte line RT7 that served as control [72]. The cancer cell lines originated from ten stage 2 (T2) and one stage 4 (T4) frozen primary samples. The expression levels of the microRNA genes were examined using the Tan Man microRNA assay (Applied Biosystems). Eleven micro-RNAs were up-regulated by at least 1.5-fold expression or higher and 54 were downregulated by less than 0.5 -fold expression in the cancer 
cell lines compared to RT7. The latter group included micrRNA-137, microRNA-139a, mcroRNA-133b and microRNA-138 [72].

The mirVana miRNA bioarray system from Ambion (Austin, TX, USA) was used in two studies aiming to provide a microRNA expression profile for head and neck cancers including oral cavity tumours. This microarray platform was used by Avissar et al. in 2009 to determine microRNA expression of 662 microRNAs in 16 fresh-frozen HNSCC tumours, 5 nondiseased head and neck epithelial tissues, and 2 individual HNSCC cell lines in one study [구]. Eleven microRNAs, including microRNA-21, were up-regulated and one was down-regulated, (microRNA-375). This study demonstrated a significant variation of microRNA expression between tissue samples and cell lines putting emphasis on the possibility that cultured cell lines maybe not appropriate for microRNA profiling of cancer. In the second study Ramdas et al. in 2009 employing the same microRNA microarray platform five tumour samples from four subsites, that included the tongue ( 2 out of 5 ) and floor of the mouth

Table 2. Studies demonstrating microRNA deregulation in head and neck/oral cavity cancer (HNOCC)

\begin{tabular}{|c|c|c|}
\hline Author & Year & Materials \\
\hline Jiang et al. & 2005 & $\begin{array}{c}32 \text { cell lines } \\
\text { various cancers }\end{array}$ \\
\hline Tran et al. & 2007 & 9 cell lines HNOCC \\
\hline Chang et al. & 2008 & $\begin{array}{c}4 \text { HNOCC cell lines, } 4 \text { tumour } \\
\text { tissue samples and } 4 \text { normal } \\
\text { tissue control }\end{array}$ \\
\hline
\end{tabular}

\begin{tabular}{|c|c|c|}
\hline Wong et al. & 2008 & $\begin{array}{c}4 \text { tumour tissue samples from } \\
\text { OT cancer and } 4 \text { paired normal } \\
\text { controls }\end{array}$ \\
\hline Kozaki et al. & 2008 & $\begin{array}{l}18 \text { OSCC cancer cell lines, } \\
11 \text { primary frozen OSCC samples } \\
\text { and immortalized keratinocyte } \\
\text { line RT } 17 \text { as control }\end{array}$ \\
\hline Avissar et al. & 2009 & $\begin{array}{c}16 \text { fresh-frozen HNOCC tumours, } \\
5 \text { non diseased epithelial tissues } \\
\text { and } 2 \text { HNOCC cell lines }\end{array}$ \\
\hline
\end{tabular}

Cancer cells were clustered based on tissue of origin

No controls. First study to provide a genome-wide survey of mature microRNA in head and neck

23 microRNAs up-regulated, among them let-7, microRNA-16, microRNA-21 and microRNA-205 (some known carcinogens) 22 microRNAs down-regulated

8 microRNAs up-regulated in cancer tissue versus control among them microRNA-21, microRNA-18, microRNA-19, microRNA-29c, microRNA-142, microRNA-3p, microRNA-155, microRNA-146b and let-7 (some known to be involved in carcinogenesis)

1 microRNA down-regulated, microRNA-494

24 microRNAs up-regulated among them microRNA-184 and microR $N$ A-21

(known to be involved in carcinogenesis)

13 microRNAs down-regulated among them microRNA-100, microRNA125, microRNA-133a and microRNA-133b

11 microRNAs up-regulated among them microRNA-374, microRNA-340, microRNA-224, microRNA-31, microRNA-9

(some known to be involved in carcinogenesis)

54 microRNAs down-regulated among them micrRNA-137, microRNA$139 a, \boldsymbol{m c r o R N A} \mathbf{A} \mathbf{1 3 3 \boldsymbol { b }}$ and microRNA-138

11 microRNAs up-regulated among them microRNA-21 (known to be involved in carcinogenesis)

1 microRNA down-regulated, microRNA-375

16 microRNAs up-regulated including microRNA-21, microRNA-7, microRNA-34b, microRNA-155, microRNA-182, microRNA-15b, microRNA-185, let-7

(some known to be involved in carcinogenesis)

Ramdas et al. 2009 and FOM and adjacent normal

4 microRNAs down-regulated among them microRNA-23b, microRNA$125 a$, microRNA-125b

The study demonstrated potential for stratification of tumour versus adjacent normal tissue based on the differential expression of microRNA and their targeted genes

13 microRNAs up-regulated among them microRNA-21 (known to be

15 OSCC tumour samples

Scapoli et al. $\quad 2010 \quad$ (8 without known metastasis and 7 with nodal involvement)

Lajer et al.
2011
51 OSCC and pharyngeal cancer samples and 40 controls

\section{involved in carcinogenesis)}

4 microRNAs down-regulated among them let-7i, microRNA-155 and microRNA-146a that were found to characterize disease progression nodal metastasis

114 microRNAs deregulated between OSCC and normal control among them up-regulation of microRNA-31 and down-regulation of microRNA-375 were the most significant

38 microRNAs deregulated between pharyngeal cancers and normal 21 microRNAs deregulation were associated with HPV infection among them microRNA-127-3p and microRNA-363 
(1 out of 5) were compared to normal tissue harvested from adjacent to the tumour [74]. In addition to identifying 16 up-regulated microRNAs (including microRNA-21) and 4 down-regulated microRNAs the study demonstrated potential for stratification of tumour versus adjacent normal tissue based on the differential expression of microRNA and their targeted genes.

A comprehensive list of the studies demonstrating microRNA deregulation in head and neck/oral cancer is provided in Table 2.

Most recently, Clague et al. in 2009 examined the potential role of microRNA polymorphism in identifying patients with oral premalignant lesions (OPL) that maybe at high risk for progression into cancer [75]. They concluded that individual and combined genotypes of microRNA-related variants could potentially be used to predict risk for progression. The potential role of microRNAs in tumour progression was investigated by Scapoli et al. using microarray analysis the group examined 15 oral cancers $(8$ without evidence of metastasis and 7 with nodal involvement) and among the 19 deregulated microRNAs they identified three (let-7i, microRNA-155 and microRNA$146 a)$ to be associated with disease progression, signified by nodal involvement [ㄷ]. Lajer et al. in 2011 identified differences in microRNA expression patterns of normal epithelia and squamous cell carcinoma of the oral cavity and developed a molecular classifier that included 61 microRNAs and provided 93\% accuracy [77]. In addition the group concluded that HPV (human papilloma virus) infected tumours may have a distinct clinical behaviour potentially due to influence of HPV on microRNA.

\section{MicroRNA deregulation in oral cancer and prognosis}

In addition to exploring microRNA deregulation some studies have attempted to demonstrate an association between microRNA expression in head and neck including oral cavity cancer and survival. MicroRNA expression profiles from 64 squamous cell carcinomas, that included 31 oral cavity tumours, carried in fresh specimens and adjacent normal tissue identified microRNAs let-7 and microRNA-205 as poor prognosticators in survival. Using a custom microRNA microarray representing a total of 236 human microRNA genes deregulation was identified in 49. An average of 2-fold lower expression was demonstrated for 43 , while at least a 2 -fold higher expression in tumours versus controls was found for 6 microRNAS. Five microRNA genes (microRNA-21, microRNA-1, microRNA-133, microRNA-205, and let-7d) were selected for quantification based on existing evidence of their deregulation in head and neckcancers from previous studies. Findings were consistent with previous studies: higher expression levels of microRA-21 in tumours versus controls and lower expression levels of microRNA-205 and let-7d in tumours versus controls. When investigating microRNA expression and clinical outcomes the reduced expression of let- $7 d$ and microRNA-205 combined were significant predictors of cancer progression independent of site [78]. Another interesting population-based case-control study that included 513 cancers (283 oral cancer, 132 pharyngeal and 98 laryngeal cancers) and 597 controls (matched to cases by gender, age and town of residency) examined the let-7 microRNA-binding site polymorphism in the KRAS 3' UTR that arises in the let-7 complementary site. This leads to a KRASLCS6 variant allele that alters the expression of KRAS and levels of let-7. The interest in this phenomenon was driven by observations that when this variant allele was identified in lung cancers it was associated with poor outcome [79]. The let-7 microRNA family regulates KRAS functioning as tumour suppressor gene. Lung, pancreas and colon adenocarcinomas activation of KRAs proto-oncogene via mutation is a well documented phenomenon [80]. Although KRAS mutations are rare in cancers of the head and neck, amplifications of KRAS have been reported in squamous cell carcinomas originating from this site $[\underline{81,82] . ~ I n ~ t h i s ~ s t u d y ~ t w o ~ i m p o r t a n t ~ o b s e r v a t i o n s ~ w e r e ~}$ made: KRAS-LCS6 variant allele was significantly associated with poor prognosis and the prognosis was worse in cancers originating in the oral cavity [79].

Metastasis is the major distinctive event in malignancy progression and severely impacts on prognosis. Using three pairs of cancer cell lines from the head and neck with differences in migration and invasion Liu et al. in 2009 identified several microRNAs to be deregulated many of them previously implicated in tumorigenesis and metastasis [83]. These included let-7 family members, microRNA-7, microRNA-16, microRNA-21, microRNA-27 family, microRNA-98, microRNA-99b, microRNA-101, microRNA106b, microRNA-125, microRNA-138, microRNA-193, microRNA-200a, microRNA-203, and microRNA-224 [69, 84-102]. Among the identified microRNAderegulations, reduced expression of microRNA-138 was consistently observed in the highly invasive cell lines [103]. Downregulation of microRNA-138 has been previously observed in SCC of the tongue, thyroid carcinoma, lung cancer in never smokers and has been implicated in multidrug resistance of leukaemia cells $[\underline{71}, \underline{99}, \underline{103}, \underline{104}]$.

\section{DISCUSSION}

The majority of these studies especially early on utilized 
cell lines originating from different sub-sites of the head and neck such as hypopharynx, oral and base of tongue or larynx. The substantial differences in behaviour, response to treatment and pathogenesis among these tumours is well known and may have contributed to some contradicting findings. Furthermore, cancer cells lines were not compared to controls or tissue from tumours in some of the studies. This may as well have contributed to some extend to the confusing reports regarding some microRNAs. Additional limitation of the studies using cancer lines that prevents definitive conclusions is that the cultured cells may not demonstrate the same profiles as the cancers of origin. It has been suggested actually that the in vitro conditions, inclusion of synthetic medium and addition of fetal bovine serum may affect the expression profiles of microRNAs [105].

\section{CONCLUSIONS}

Significant progress has been made in identification of specific microRNAs that are consistently deregulated in

Table 3. Commonly deregulated microRNAs in head and neck/oral cavity cancer (HNOCC) and their proposed target genes

\begin{tabular}{|c|c|c|}
\hline $\begin{array}{l}\text { MicroRNAs } \\
\text { deregulated } \\
\text { in HNOCC }\end{array}$ & $\begin{array}{l}\text { Proposed Target gene(s) } \\
\text { additional mechanisms and findings }\end{array}$ & $\begin{array}{l}\text { Author / Year / } \\
\text { Journal }\end{array}$ \\
\hline $\operatorname{microRNA-184}$ & c-Myc & $\begin{array}{l}\text { Wong et al. / } 2008 \text { / Clin. } \\
\text { Cancer Research. }\end{array}$ \\
\hline $\begin{array}{l}\operatorname{micr} R N A-133 a \\
\quad \text { and } \\
\text { microRNA-133b }\end{array}$ & $\begin{array}{l}\text { PKM2 } \\
\text { (pyruvate kinase type 2) }\end{array}$ & $\begin{array}{l}\text { Wong et al. / } 2008 \text { / Int. J. } \\
\text { Cancer. }\end{array}$ \\
\hline $\begin{array}{l}\text { microRNa-137 } \\
\quad \text { and } \\
\text { microRNA-193a }\end{array}$ & $\begin{array}{l}\text { CDK6 } \\
\qquad \begin{array}{l}\text { (cyclin dependant kinase 6) } \\
\text { E2F transcription factor 6 }\end{array} \\
\text { Additionally it was demonstrated that these two microRNAs are tumour suppressors } \\
\text { epigenetically silenced during oral carcinogenesis through DNA hypermethylation }\end{array}$ & $\begin{array}{l}\text { Kozaki et al. / } 2008 \text { / Cancer } \\
\text { Research. }\end{array}$ \\
\hline $\operatorname{microRNA-15a}$ & $\begin{array}{l}\qquad \text { Cyclin E } \\
\text { PKCa (protien kinase c alpha) down regulates microRNA-15a that directly inhibits } \\
\text { cyclin E }\end{array}$ & $\begin{array}{l}\text { Cohen et al /2009 / Cancer } \\
\text { Research }\end{array}$ \\
\hline microRNA-21 & $\begin{array}{l}\text { TPM1 and PTEN } \\
\text { (tropomyosin } 1 \text { and phosphatase tensin) } \\
\text { Most likely actual role of microRNA-21 in tumorigenesis is accomplished by } \\
\text { complex interactions with tumour / metastasis and suppressor genes }\end{array}$ & $\begin{array}{l}\text { Zhu et al. / } 2007 \text { / Biol. Chem. } \\
\text { Li et al. / } 2008 \text { / Clin. Cancer } \\
\text { Research. } \\
\text { Chang et al. / } 2008 \text { / J. Dent. } \\
\text { Res. }\end{array}$ \\
\hline $\begin{array}{l}\text { microRNA-103 } \\
\quad \text { and } \\
\text { microRNA-107 }\end{array}$ & $\begin{array}{c}\text { PDCD4 } \\
\text { (programmed cell death protein 4) } \\
\text { TGFBR3 } \\
\text { (tumour growth factor receptor beta 3) }\end{array}$ & $\begin{array}{l}\text { Ramdas et al. / } 2008 \text { / Head } \\
\text { and Neck. }\end{array}$ \\
\hline microRNA-205 & $\begin{array}{c}\text { DHFR } \\
\text { (dihydrofolate reductase) }\end{array}$ & $\begin{array}{l}\text { Nakashima et al. / } 2008 \text { / Acta } \\
\text { Otolar. }\end{array}$ \\
\hline & $\begin{array}{l}\text { let- } 7 \text { has been associated in oral cancers with decreased survival in cases with the } \\
\text { KRAS-LCS6 genotype variant }\end{array}$ & $\begin{array}{l}\text { Christensen et al. / } 2009 \text { / } \\
\text { Carcinogenesis. }\end{array}$ \\
\hline $\begin{array}{l}\text { microRNA-125b } \\
\quad \text { and } \\
\text { microRNA-100 }\end{array}$ & $\begin{array}{c}\text { KLF13, CXCL11 and FOXA1 } \\
\text { and } \\
\text { EGFR3 } \\
\text { (epidermoid growth factor receptor 3) }\end{array}$ & $\begin{array}{l}\text { Henson et al. / } 2009 \text { / Genes } \\
\text { Chromosomes Cancer. }\end{array}$ \\
\hline microRNA-222 & $\begin{array}{c}\text { MMP1 } \\
\text { (matrix metalloproteinase 1) } \\
\text { SOD2 } \\
\text { (manganese superoxide dismutase 2) }\end{array}$ & $\begin{array}{l}\text { Liu et al / 2009/ Cancer } \\
\text { Genom. Proteom. }\end{array}$ \\
\hline microRNA-24 & $\begin{array}{l}\text { DND1 } \\
\text { (dead end 1, an RNA binding protein which in turn regulates a group of } \\
\text { downstream genes at post-transcriptional levels) }\end{array}$ & Liu et al. / 2009/ FEBS letters. \\
\hline microRNA-7 & $\begin{array}{c}\text { IGF1R } \\
\text { (insulin-like growth factor1 receptor) }\end{array}$ & $\begin{array}{l}\text { Jiang et al. / } 2010 \text { / Biochemical } \\
\text { Journal. }\end{array}$ \\
\hline $\operatorname{microRNA-138}$ & $\begin{array}{c}\text { GNAI2 } \\
\text { (G protein alpha inhibiting activity polypeptide } 2)\end{array}$ & $\begin{array}{l}\text { Jiang et al. / } 2010 / \text { International } \\
\text { J. of Cancer. }\end{array}$ \\
\hline
\end{tabular}


oral cavity cancers. From the available studies, it can be concluded that microRNA-21 and let-7 are among the microRNAs found to be always up-regulated in cancers of the oral cavity and oropharynx versus controls while microRNA-133a and microRNA-133b are consistently down-regulated. Among the deregulated microRNAs, several have been functionally validated and their potential target genes have been identified (Table 3). Several other microRNAs known to be involved in carcinogenesis are reported with some conflicting findings potentially due to the study limitations mentioned earlier. Additional evidence exists on specific roles of these molecules and their involvement in pathways, known to be altered in cancer of the oral cavity and oropharynx as shown in table 3 .
The expanding knowledge of specific roles of certain microRNAs is further contributing to our understanding of the complexity of tumour progression and behaviour. Consideration of this information and incorporation into treatment modalities through targeted therapy could potentially enhance our abilities to improve outcome especially when other established therapies have failed.

\section{ACKNOWLEDGMENTS AND DISCLOSURE STATEMENTS}

The authors have no conflict of interest to declare.

\section{REFERENCES}

1. Jemal A, Siegel R, Xu J, Ward E. Cancer statistics, 2010. CA Cancer J Clin. 2010 Sep-Oct;60(5):277-300. Epub 2010 Jul 7. Erratum in: CA Cancer J Clin. 2011 Mar-pr;61(2):133-4. [Medline: 20610543] [doi: 10.3322/caac.20073]

2. Carvalho AL, Nishimoto IN, Califano JA, Kowalski LP. Trends in incidence and prognosis for head and neck cancer in the United States: a site-specific analysis of the SEER database. Int J Cancer. 2005 May 1;114(5):806-16. [Medline: 15609302] [doi: 10.1002/ijc.20740]

3. Shiboski $\mathrm{CH}$, Schmidt BL, Jordan RC. Racial disparity in stage at diagnosis and survival among adults with oral cancer in the US. Community Dent Oral Epidemiol. 2007 Jun;35(3):233-40. [Medline: 17518970] [doi: 10.1111/j.0301-5661.2007.00334.x]

4. O'Connor SJ. Continuing disparities in survival rates between younger and older cancer patients in Europe. Might oral chemotherapy provide one solution to the problem? Eur J Cancer Care (Engl). 2010 Jul;19(4):421-3. [Medline: 20642624] [doi: 10.1111/j.1365-2354.2010.01200.x]

5. Zini A, Czerninski R, Sgan-Cohen HD. Oral cancer over four decades: epidemiology, trends, histology, and survival by anatomical sites. J Oral Pathol Med. 2010 Apr;39(4):299-305. Epub 2009 Dec 15. [Medline: 20040019] [doi: 10.1111/j.1600-0714.2009.00845.x]

6. Rusthoven KE, Raben D, Song JI, Kane M, Altoos TA, Chen C. Survival and patterns of relapse in patients with oral tongue cancer. J Oral Maxillofac Surg. 2010 Mar;68(3):584-9. Epub 2009 Nov 25. [Medline: 19939533] [doi:10.1016/j.joms.2009.03.056]

7. Deschamps DR, Spencer HJ, Kokoska MS, Spring PM, Vural EA, Stack BC Jr. Implications of head and neck cancer treatment failure in the neck. Otolaryngol Head Neck Surg. 2010 May;142(5):722-7. [Medline: 20416463] [doi: 10.1016/j.otohns.2010.01.026]

8. Zhu E, Zhao F, Xu G, Hou H, Zhou L, Li X, Sun Z, Wu J. mirTools: microRNA profiling and discovery based on high-throughput sequencing. Nucleic Acids Res. 2010 Jul;38(Web Server issue):W392-7. Epub 2010 May 16. [Medline: 20478827] [FREE Full Text]

9. Liu X, Chen Z, Yu J, Xia J, Zhou X. MicroRNA profiling and head and neck cancer. Comp Funct Genomics. 2009:837514. Epub 2009 Jun 1. [Medline: 19753298] [FREE Full Text]

10. Chang SS, Jiang WW, Smith I, Poeta LM, Begum S, Glazer C, Shan S, Westra W, Sidransky D, Califano JA. MicroRNA alterations in head and neck squamous cell carcinoma. Int J Cancer. 2008 Dec 15;123(12):2791-7. [Medline: 18798260] [doi: $10.1002 /$ ijc. 23831 ]

11. Carninci, P., et al. The transcriptional landscape of the mammalian genome. Science. 2005 Sep 2;309(5740):1559-63. Erratum in: Science. 2006 Mar 24;311(5768):1713. [Medline: 16141072] [doi: 10.1126/science.1112014]

12. Wiemer EA. The role of microRNAs in cancer: no small matter. Eur J Cancer. 2007 Jul;43(10):1529-44. Epub 2007 May 24. Review. [Medline: 17531469] [doi: 10.1016/j.ejca.2007.04.002]

13. Fire A, Albertson D, Harrison SW, Moerman DG. Production of antisense RNA leads to effective and specific inhibition of gene expression in C. elegans muscle. Development. 1991 Oct;113(2):503-14. [Medline: 1782862] [FREE Full Text]

14. Hannon GJ. RNA interference. Nature. 2002 Jul 11;418(6894):244-51. Review. [Medline: 12110901] [FREE Full Text] [doi: $10.1038 / 418244 a]$

15. Fire A, Xu S, Montgomery MK, Kostas SA, Driver SE, Mello CC. Potent and specific genetic interference by doublestranded RNA in Caenorhabditis elegans. Nature. 1998 Feb 19;391(6669):806-11. [Medline: 9486653] [FREE Full Text] [doi: $\underline{10.1038 / 35888}$ ] 
16. Reinhart BJ, Slack FJ, Basson M, Pasquinelli AE, Bettinger JC, Rougvie AE, Horvitz HR, Ruvkun G. The 21-nucleotide let-7 RNA regulates developmental timing in Caenorhabditis elegans. Nature. 2000 Feb 24;403(6772):901-6. [Medline: 10706289] [FREE Full Text] [doi: 10.1038/35002607]

17. Lee ST, Chu K, Oh HJ, Im WS, Lim JY, Kim SK, Park CK, Jung KH, Lee SK, Kim M, Roh JK. Let-7 microRNA inhibits the proliferation of human glioblastoma cells. J Neurooncol. 2011 Mar;102(1):19-24. Epub 2010 Jul 7. [Medline: 20607356] [doi: 10.1007/s11060-010-0286-6]

18. Lee I, Ajay SS, Chen H, Maruyama A, Wang N, McInnis MG, Athey BD. Discriminating single-base difference miRNA expressions using microarray Probe Design Guru (ProDeG). Nucleic Acids Res. 2008 Mar;36(5):e27. Epub 2008 Jan 21. [Medline: 18208839] [FREE Full Text] [doi: 10.1093/nar/gkm1165]

19. Lee YS, Dutta A. The tumor suppressor microRNA let-7 represses the HMGA2 oncogene. Genes Dev. 2007 May 1;21(9):1025-30. Epub 2007 Apr 16. [Medline: 17437991] [FREE Full Text] [doi: 10.1101/gad.1540407]

20. Lee YS, Dutta A. MicroRNAs: small but potent oncogenes or tumor suppressors. Curr Opin Investig Drugs. 2006 Jun;7(6):560-4. Review. [Medline: 16784027]

21. Lee RC, Ambros V. An extensive class of small RNAs in Caenorhabditis elegans. Science. 2001 Oct 26;294(5543):862-4. [Medline: 11679672] [doi: 10.1126/science.1065329]

22. Gartel AL, Kandel ES. RNA interference in cancer. Biomol Eng. 2006 Mar;23(1):17-34. Epub 2006 Feb 8. Review. [Medline: 16466964] [doi: 10.1016/j.bioeng.2006.01.002]

23. Wightman B, Ha I, Ruvkun G. Posttranscriptional regulation of the heterochronic gene lin-14 by lin4 mediates temporal pattern formation in C. elegans. Cell. 1993 Dec 3;75(5):855-62. [Medline: 8252622] [doi: 10.1016/0092-8674(93)90530-4]

24. Lee RC, Feinbaum RL, Ambros V. The C. elegans heterochronic gene lin-4 encodes small RNAs with antisense complementarity to lin-14. Cell. 1993 Dec 3;75(5):843-54. [Medline: 8252621] [doi: 10.1016/0092-8674(93)90529-Y]

25. Chen PY, Meister G. microRNA-guided posttranscriptional gene regulation. Biol Chem. 2005 Dec;386(12):1205-18. Review. [Medline: 16336116] [doi: 10.1515/BC.2005.139]

26. Chen X. MicroRNA biogenesis and function in plants. FEBS Lett. 2005 Oct 31;579(26):5923-31. Epub 2005 Aug 9. Review. [Medline: 16144699] [doi: 10.1016/j.febslet.2005.07.071]

27. Schwarz DS, Hutvágner G, Du T, Xu Z, Aronin N, Zamore PD. Asymmetry in the assembly of the RNAi enzyme complex. Cell. 2003 Oct 17;115(2):199-208. [Medline: 14567917] [doi: 10.1016/S0092-8674(03)00759-1]

28. Ruby JG, Jan C, Player C, Axtell MJ, Lee W, Nusbaum C, Ge H, Bartel DP. Large-scale sequencing reveals 21U-RNAs and additional microRNAs and endogenous siRNAs in C. elegans. Cell. 2006 Dec 15;127(6):1193-207. [Medline: 17174894] [doi: 10.1016/j.cell.2006.10.040]

29. Du T, Zamore PD. microPrimer: the biogenesis and function of microRNA. Development. 2005 Nov;132(21):4645-52. Review. [Medline: 16224044] [FREE Full Text] [doi: 10.1242/dev.02070]

30. Pratt AJ, MacRae IJ. The RNA-induced silencing complex: a versatile gene-silencing machine. J Biol Chem. 2009 Jul 3;284(27):17897-901. Epub 2009 Apr 1. Review. [Medline: 19342379] [FREE Full Text] [doi: 10.1074/jbc.R900012200]

31. Pham JW, Sontheimer EJ. Molecular requirements for RNA-induced silencing complex assembly in the Drosophila RNA interference pathway. J Biol Chem. 2005 Nov 25;280(47):39278-83. Epub 2005 Sep 22. [Medline: 16179342] [FREE Full Text] [doi: 10.1074/jbc.M509202200]

32. Ohnishi Y, Tokunaga K, Hohjoh H. Influence of assembly of siRNA elements into RNA-induced silencing complex by fork-siRNA duplex carrying nucleotide mismatches at the 3'- or 5'-end of the sense-stranded siRNA element. Biochem Biophys Res Commun. 2005 Apr 8;329(2):516-21. [Medline: 15737617] [doi: 10.1016/j.bbrc.2005.02.012]

33. Bernstein E, Kim SY, Carmell MA, Murchison EP, Alcorn H, Li MZ, Mills AA, Elledge SJ, Anderson KV, Hannon GJ. Dicer is essential for mouse development. Nat Genet. 2003 Nov;35(3):215-7. Epub 2003 Oct 5. Erratum in: Nat Genet. 2003 Nov;35(3):287. [Medline: 14528307] [doi: 10.1038/ng1253]

34. Förstemann K, Tomari Y, Du T, Vagin VV, Denli AM, Bratu DP, Klattenhoff C, Theurkauf WE, Zamore PD. Normal microRNA maturation and germ-line stem cell maintenance requires Loquacious, a double-stranded RNA-binding domain protein. PLoS Biol. 2005 Jul;3(7):e236. Epub 2005 May 24. [Medline: 15918770] [FREE Full Text] [doi: 10.1371/journal.pbio.0030236]

35. Ketting RF, Fischer SE, Bernstein E, Sijen T, Hannon GJ, Plasterk RH. Dicer functions in RNA interference and in synthesis of small RNA involved in developmental timing in C. elegans. Genes Dev. 2001 Oct 15;15(20):2654-9. [Medline: 11641272] [FREE Full Text] [doi: 10.1101/gad.927801]

36. Wienholds E, Koudijs MJ, van Eeden FJ, Cuppen E, Plasterk RH. The microRNA-producing enzyme Dicer1 is essential for zebrafish development. Nat Genet. 2003 Nov;35(3):217-8. Epub 2003 Oct 5. [Medline: 14528306] [doi: $10.1038 / \mathrm{ng} 1251]$

37. Suárez Y, Fernández-Hernando C, Yu J, Gerber SA, Harrison KD, Pober JS, Iruela-Arispe ML, Merkenschlager M, Sessa WC. Dicer-dependent endothelial microRNAs are necessary for postnatal angiogenesis. Proc Natl Acad Sci U S A. 2008 Sep 16;105(37):14082-7. [Medline: 18779589] [FREE Full Text] [doi: 10.1073/pnas.0804597105]

38. Cobb BS, Nesterova TB, Thompson E, Hertweck A, O’Connor E, Godwin J, Wilson CB, Brockdorff N, Fisher AG, Smale ST, Merkenschlager M. T cell lineage choice and differentiation in the absence of the RNase III enzyme Dicer. J Exp Med. 2005 May 2;201(9):1367-73. [Medline: 15867090] [FREE Full Text] [doi: 10.1084/jem.20050572] 
39. Andl T, Murchison EP, Liu F, Zhang Y, Yunta-Gonzalez M, Tobias JW, Andl CD, Seykora JT, Hannon GJ, Millar SE. The miRNA-processing enzyme dicer is essential for the morphogenesis and maintenance of hair follicles. Curr Biol. 2006 May 23;16(10):1041-9. Epub 2006 May 11. [Medline: 16682203] [FREE Full Text] [doi: 10.1016/j.cub.2006.04.005]

40. Harris KS, Zhang Z, McManus MT, Harfe BD, Sun X. Dicer function is essential for lung epithelium morphogenesis. Proc Natl Acad Sci U S A. 2006 Feb 14;103(7):2208-13. Epub 2006 Feb 1. [Medline: 16452165] [FREE Full Text] [doi: 10.1073/pnas.0510839103]

41. Harfe BD, McManus MT, Mansfield JH, Hornstein E, Tabin CJ. The RNaseIII enzyme Dicer is required for morphogenesis but not patterning of the vertebrate limb. Proc Natl Acad Sci U S A. 2005 Aug 2;102(31):10898-903. Epub 2005 Jul 22. [Medline: 16040801] [FREE Full Text] [doi: 10.1073/pnas.0504834102]

42. Yi R, O'Carroll D, Pasolli HA, Zhang Z, Dietrich FS, Tarakhovsky A, Fuchs E.Morphogenesis in skin is governed by discrete sets of differentially expressed microRNAs. Nat Genet. 2006 Mar;38(3):356-62. Epub 2006 Feb 5. [Medline: 16462742 ] [doi: $10.1038 / n g 1744]$

43. Chen CZ, Li L, Lodish HF, Bartel DP. MicroRNAs modulate hematopoietic lineage differentiation. Science. 2004 Jan 2;303(5654):83-6. Epub 2003 Dec 4. [Medline: 14657504] [doi: 10.1126/science.1091903]

44. Chang TC, Yu D, Lee YS, Wentzel EA, Arking DE, West KM, Dang CV, Thomas-Tikhonenko A, Mendell JT. Widespread microRNA repression by Myc contributes to tumorigenesis. Nat Genet. 2008 Jan;40(1):43-50. Epub 2007 Dec 9. [Medline: 18066065] [FREE Full Text] [doi: 10.1038/ng.2007.30]

45. Chen JF, Mandel EM, Thomson JM, Wu Q, Callis TE, Hammond SM, Conlon FL, Wang DZ. The role of microRNA-1 and microRNA-133 in skeletal muscle proliferation and differentiation. Nat Genet. 2006 Feb;38(2):228-33. Epub 2005 Dec 25. [Medline: 16380711] [FREE Full Text] [doi: 10.1038/ng1725]

46. Lagos-Quintana M, Rauhut R, Lendeckel W, Tuschl T. Identification of novel genes coding for small expressed RNAs. Science. 2001 Oct 26;294(5543):853-8. [Medline: 11679670] [doi: 10.1126/science.1064921]

47. Nakajima N, Takahashi T, Kitamura R, Isodono K, Asada S, Ueyama T, Matsubara H, Oh H. MicroRNA-1 facilitates skeletal myogenic differentiation without affecting osteoblastic and adipogenic differentiation. Biochem Biophys Res Commun. 2006 Dec 1;350(4):1006-12. Epub 2006 Oct 6. [Medline: 17045567] [doi: 10.1016/j.bbrc.2006.09.153]

48. Ambros V. The functions of animal microRNAs. Nature. 2004 Sep 16;431(7006):350-5. Review. [Medline: 15372042] [doi: 10.1038/nature02871]

49. Bartel DP. MicroRNAs: genomics, biogenesis, mechanism, and function. Cell. 2004 Jan 23;116(2):281-97. Review. [Medline: 14744438] [doi: 10.1016/S0092-8674(04)00045-5]

50. Kloosterman WP, Lagendijk AK, Ketting RF, Moulton JD, Plasterk RH. Targeted inhibition of miRNA maturation with morpholinos reveals a role for miR-375 in pancreatic islet development. PLoS Biol. 2007 Aug;5(8):e203. [Medline: 17676975] [FREE Full Text] [doi: 10.1371/journal.pbio.0050203]

51. Yang Z, Bian C, Zhou H, Huang S, Wang S, Liao L, Zhao RC. MicroRNA hsa-miR-138 inhibits adipogenic differentiation of human adipose tissue-derived mesenchymal stem cells through adenovirus EID-1. Stem Cells Dev. 2011 Feb;20(2):25967. Epub 2010 Oct 7. [Medline: 20486779] [doi: 10.1089/scd.2010.0072]

52. Lim LP, Lau NC, Garrett-Engele P, Grimson A, Schelter JM, Castle J, Bartel DP, Linsley PS, Johnson JM. Microarray analysis shows that some microRNAs downregulate large numbers of target mRNAs. Nature. 2005 Feb 17;433(7027):76973. Epub 2005 Jan 30. [Medline: 15685193] [doi: 10.1038/nature03315]

53. Farh KK, Grimson A, Jan C, Lewis BP, Johnston WK, Lim LP, Burge CB, Bartel DP. The widespread impact of mammalian MicroRNAs on mRNA repression and evolution. Science. 2005 Dec 16;310(5755):1817-21. Epub 2005 Nov 24. [Medline: 16308420] [doi: 10.1126/science.1121158]

54. Sood P, Krek A, Zavolan M, Macino G, Rajewsky N. Cell-type-specific signatures of microRNAs on target mRNA expression. Proc Natl Acad Sci U S A. 2006 Feb 21;103(8):2746-51. Epub 2006 Feb 13. [Medline: 16477010] [FREE Full Text] [doi: 10.1073/pnas.0511045103]

55. Poy MN, Eliasson L, Krutzfeldt J, Kuwajima S, Ma X, Macdonald PE, Pfeffer S, Tuschl T, Rajewsky N, Rorsman P, Stoffel M. A pancreatic islet-specific microRNA regulates insulin secretion. Nature. 2004 Nov 11;432(7014):226-30. [Medline: 15538371] [doi: 10.1038/nature03076]

56. Krützfeldt J, Rajewsky N, Braich R, Rajeev KG, Tuschl T, Manoharan M, Stoffel M. Silencing of microRNAs in vivo with 'antagomirs'. Nature. 2005 Dec 1;438(7068):685-9. Epub 2005 Oct 30. [Medline: 16258535] [doi: $10.1038 /$ nature 04303 ]

57. Esau C, Davis S, Murray SF, Yu XX, Pandey SK, Pear M, Watts L, Booten SL, Graham M, McKay R, Subramaniam A, Propp S, Lollo BA, Freier S, Bennett CF, Bhanot S, Monia BP. miR-122 regulation of lipid metabolism revealed by in vivo antisense targeting. Cell Metab. 2006 Feb;3(2):87-98. [Medline: 16459310] [doi: 10.1016/j.cmet.2006.01.005]

58. Schratt GM, Tuebing F, Nigh EA, Kane CG, Sabatini ME, Kiebler M, Greenberg ME. A brain-specific microRNA regulates dendritic spine development. Nature. 2006 Jan 19;439(7074):283-9. Erratum in: Nature. 2006 Jun 15;441(7095):902. [Medline: 16421561] [doi: 10.1038/nature04367]

59. Vo N, Klein ME, Varlamova O, Keller DM, Yamamoto T, Goodman RH, Impey S. A cAMP-response element binding protein-induced microRNA regulates neuronal morphogenesis. Proc Natl Acad Sci U S A. 2005 Nov 8;102(45):1642631. Epub 2005 Oct 31. Erratum in: Proc Natl Acad Sci U S A. 2006 Jan 17;103(3):825. [Medline: 16260724] [FREE Full Text] [doi: 10.1073/pnas.0508448102] 
60. Christensen M, Schratt GM. microRNA involvement in developmental and functional aspects of the nervous system and in neurological diseases. Neurosci Lett. 2009 Dec 4;466(2):55-62. Epub 2009 Apr 23. Review. [Medline: 19393715] [doi: 10.1016/j.neulet.2009.04.043]

61. Siegel G, Obernosterer G, Fiore R, Oehmen M, Bicker S, Christensen M, Khudayberdiev S, Leuschner PF, Busch CJ, Kane C, Hübel K, Dekker F, Hedberg C, Rengarajan B, Drepper C, Waldmann H, Kauppinen S, Greenberg ME, Draguhn A, Rehmsmeier M, Martinez J, Schratt GM. A functional screen implicates microRNA-138-dependent regulation of the depalmitoylation enzyme APT1 in dendritic spine morphogenesis. Nat Cell Biol. 2009 Jun;11(6):705-16. Epub 2009 May 24. [Medline: 19465924] [doi: 10.1038/ncb1876]

62. Morton SU, Scherz PJ, Cordes KR, Ivey KN, Stainier DY, Srivastava D. microRNA-138 modulates cardiac patterning during embryonic development. Proc Natl Acad Sci U S A. 2008 Nov 18;105(46):17830-5. Epub 2008 Nov 12. [Medline: 19004786] [FREE Full Text] [doi: 10.1073/pnas.0804673105]

63. Bushati N, Cohen SM. microRNA functions. Annu Rev Cell Dev Biol. 2007;23:175-205. Review. [Medline: 17506695] [doi: 10.1146/annurev.cellbio.23.090506.123406]

64. Chang TC, Mendell JT. microRNAs in vertebrate physiology and human disease. Annu Rev Genomics Hum Genet. 2007;8:215-39. Review. [Medline: 17506656] [doi: 10.1146/annurev.genom.8.080706.092351]

65. Lu J, Getz G, Miska EA, Alvarez-Saavedra E, Lamb J, Peck D, Sweet-Cordero A, Ebert BL, Mak RH, Ferrando AA, Downing JR, Jacks T, Horvitz HR, Golub TR. MicroRNA expression profiles classify human cancers. Nature. 2005 Jun 9;435(7043):834-8. [Medline: 15944708] [FREE Full Text] [doi: 10.1038/nature03702]

66. Rosenfeld N, Aharonov R, Meiri E, Rosenwald S, Spector Y, Zepeniuk M, Benjamin H, Shabes N, Tabak S, Levy A, Lebanony D, Goren Y, Silberschein E, Targan N, Ben-Ari A, Gilad S, Sion-Vardy N, Tobar A, Feinmesser M, Kharenko O, Nativ O, Nass D, Perelman M, Yosepovich A, Shalmon B, Polak-Charcon S, Fridman E, Avniel A, Bentwich I, Bentwich Z, Cohen D, Chajut A, Barshack I. MicroRNAs accurately identify cancer tissue origin. Nat Biotechnol. 2008 Apr;26(4):462-9. Epub 2008 Mar 23. [Medline: 18362881] [doi: 10.1038/nbt1392]

67. Jiang J, Lee EJ, Gusev Y, Schmittgen TD. Real-time expression profiling of microRNA precursors in human cancer cell lines. Nucleic Acids Res. 2005 Sep 28;33(17):5394-403. Print 2005. [Medline: 16192569] [FREE Full Text]

68. Tran N, McLean T, Zhang X, Zhao CJ, Thomson JM, O'Brien C, Rose B. MicroRNA expression profiles in head and neck cancer cell lines. Biochem Biophys Res Commun. 2007 Jun 22;358(1):12-7. Epub 2007 Apr 9. [Medline: 17475218] [doi: $10.1016 / j . b b r c .2007 .03 .201]$

69. Hebert C, Norris K, Scheper MA, Nikitakis N, Sauk JJ. High mobility group A2 is a target for miRNA-98 in head and neck squamous cell carcinoma. Mol Cancer. 2007 Jan 14;6:5. [Medline: 17222355] [FREE Full Text] [doi: 10.1186/1476-4598-6-5]

70. Wong TS, Liu XB, Chung-Wai Ho A, Po-Wing Yuen A, Wai-Man Ng R, Ignace Wei W. Identification of pyruvate kinase type M2 as potential oncoprotein in squamous cell carcinoma of tongue through microRNA profiling. Int J Cancer. 2008 Jul 15;123(2):251-7. [Medline: 18464261] [doi: 10.1002/ijc.23583]

71. Wong TS, Liu XB, Wong BY, Ng RW, Yuen AP, Wei WI. Mature miR-184 as Potential Oncogenic microRNA of Squamous Cell Carcinoma of Tongue. Clin Cancer Res. 2008 May 1;14(9):2588-92. [Medline: 18451220] [FREE Full Text] [doi: 10.1158/1078-0432.CCR-07-0666]

72. Kozaki K, Imoto I, Mogi S, Omura K, Inazawa J. Exploration of tumor-suppressive microRNAs silenced by DNA hypermethylation in oral cancer. Cancer Res. 2008 Apr 1;68(7):2094-105. [Medline: 18381414] [FREE Full Text] [doi: 10.1158/0008-5472.CAN-07-5194]

73. Avissar M, Christensen BC, Kelsey KT, Marsit CJ. MicroRNA expression ratio is predictive of head and neck squamous cell carcinoma. Clin Cancer Res. 2009 Apr 15;15(8):2850-5. Epub 2009 Apr 7. [Medline: 19351747] [FREE Full Text] [doi: 10.1158/1078-0432.CCR-08-3131]

74. Ramdas L, Giri U, Ashorn CL, Coombes KR, El-Naggar A, Ang KK, Story MD. miRNA expression profiles in head and neck squamous cell carcinoma and adjacent normal tissue. Head Neck. 2009 May;31(5):642-54. [Medline: 19260130] [FREE Full Text] [doi: 10.1002/hed.21017]

75. Clague J, Lippman SM, Yang H, Hildebrandt MA, Ye Y, Lee JJ, Wu X. Genetic variation in MicroRNA genes and risk of oral premalignant lesions. Mol Carcinog. 2010 Feb;49(2):183-9. [Medline: 19851984] [doi: 10.1002/mc.20588]

76. Scapoli L, Palmieri A, Lo Muzio L, Pezzetti F, Rubini C, Girardi A, Farinella F, Mazzotta M, Carinci F. MicroRNA expression profiling of oral carcinoma identifies new markers of tumor progression. Int J Immunopathol Pharmacol. 2010 Oct-Dec;23(4):1229-34. [Medline: 21244772]

77. Lajer CB, Nielsen FC, Friis-Hansen L, Norrild B, Borup R, Garnæs E, Rossing M, Specht L, Therkildsen MH, Nauntofte B, Dabelsteen S, von Buchwald C. Different miRNA signatures of oral and pharyngeal squamous cell carcinomas: a prospective translational study. Br J Cancer. 2011 Mar 1;104(5):830-40. Epub 2011 Feb 15. [Medline: 21326242] [doi: $10.1038 /$ bjc.2011.29]

78. Childs G, Fazzari M, Kung G, Kawachi N, Brandwein-Gensler M, McLemore M, Chen Q, Burk RD, Smith RV, Prystowsky MB, Belbin TJ, Schlecht NF. Low-level expression of microRNAs let-7d and miR-205 are prognostic markers of head and neck squamous cell carcinoma. Am J Pathol. 2009 Mar;174(3):736-45. Epub 2009 Jan 29. [Medline: 19179615] [FREE Full Text] [doi: 10.2353/ajpath.2009.080731] 
79. Yanaihara N, Caplen N, Bowman E, Seike M, Kumamoto K, Yi M, Stephens RM, Okamoto A, Yokota J, Tanaka T, Calin GA, Liu CG, Croce CM, Harris CC. Unique microRNA molecular profiles in lung cancer diagnosis and prognosis. Cancer Cell. 2006 Mar;9(3):189-98. [Medline: 16530703] [doi: 10.1016/i.ccr.2006.01.025]

80. Christensen BC, Moyer BJ, Avissar M, Ouellet LG, Plaza SL, McClean MD, Marsit CJ, Kelsey KT. A let-7 microRNAbinding site polymorphism in the KRAS 3' UTR is associated with reduced survival in oral cancers. Carcinogenesis. 2009 Jun;30(6):1003-7. Epub 2009 Apr 20. [Medline: 19380522] [FREE Full Text] [doi: 10.1093/carcin/bgp099]

81. Lea IA, Jackson MA, Li X, Bailey S, Peddada SD, Dunnick JK. Genetic pathways and mutation profiles of human cancers: site- and exposure-specific patterns. Carcinogenesis. 2007 Sep;28(9):1851-8. Epub 2007 Aug 11. Review. [Medline: 17693665] [FREE Full Text] [doi: 10.1093/carcin/bgm176]

82. Van Damme N, Deron P, Van Roy N, Demetter P, Bols A, Van Dorpe J, Baert F, Van Laethem JL, Speleman F, Pauwels P, Peeters M. Epidermal growth factor receptor and K-RAS status in two cohorts of squamous cell carcinomas. BMC Cancer. 2010 May 11;10:189. [Medline: 20459770] [FREE Full Text] [doi: 10.1186/1471-2407-10-189]

83. Liu X, Jiang L, Wang A, Yu J, Shi F, Zhou X. MicroRNA-138 suppresses invasion and promotes apoptosis in head and neck squamous cell carcinoma cell lines. Cancer Lett. 2009 Dec 28;286(2):217-22. Epub 2009 Jun 21. [Medline: 19540661] [FREE Full Text] [doi: 10.1016/j.canlet.2009.05.030]

84. Yuen ST, Davies H, Chan TL, Ho JW, Bignell GR, Cox C, Stephens P, Edkins S, Tsui WW, Chan AS, Futreal PA, Stratton MR, Wooster R, Leung SY. Similarity of the phenotypic patterns associated with BRAF and KRAS mutations in colorectal neoplasia. Cancer Res. 2002 Nov 15;62(22):6451-5. [Medline: 12438234] [FREE Full Text]

85. Wang Y, Lee AT, Ma JZ, Wang J, Ren J, Yang Y, Tantoso E, Li KB, Ooi LL, Tan P, Lee CG. Profiling microRNA expression in hepatocellular carcinoma reveals microRNA-224 up-regulation and apoptosis inhibitor-5 as a microRNA-224-specific target. J Biol Chem. 2008 May 9;283(19):13205-15. Epub 2008 Mar 4. [Medline: 18319255] [FREE Full Text] [doi: 10.1074/jbc.M707629200]

86. Roush S, Slack FJ. The let-7 family of microRNAs. Trends Cell Biol. 2008 Oct;18(10):505-16. Epub 2008 Sep 4. Review. [Medline: 18774294] [doi: 10.1016/j.tcb.2008.07.007]

87. Kaddar T, Chien WW, Bertrand Y, Pages MP, Rouault JP, Salles G, Ffrench M, Magaud JP. Prognostic value of miR-16 expression in childhood acute lymphoblastic leukemia relationships to normal and malignant lymphocyte proliferation. Leuk Res. 2009 Sep;33(9):1217-23. Epub 2009 Feb 4. [Medline: 19195700] [doi: 10.1016/j.leukres.2008.12.015]

88. Kaddar T, Rouault JP, Chien WW, Chebel A, Gadoux M, Salles G, Ffrench M, Magaud JP. Two new miR-16 targets: caprin-1 and HMGA1, proteins implicated in cell proliferation. Biol Cell. 2009 Sep;101(9):511-24. [Medline: 19250063] [FREE Full Text] [doi: 10.1042/BC20080213]

89. Si ML, Zhu S, Wu H, Lu Z, Wu F, Mo YY. miR-21-mediated tumor growth. Oncogene. 2007 Apr 26;26(19):2799-803. Epub 2006 Oct 30. [Medline: 17072344] [doi: 10.1038/sj.onc.1210083]

90. Chan JA, Krichevsky AM, Kosik KS. MicroRNA-21 is an antiapoptotic factor in human glioblastoma cells. Cancer Res. 2005 Jul 15;65(14):6029-33. [Medline: 16024602] [FREE Full Text] [doi: 10.1158/0008-5472.CAN-05-0137]

91. Mertens-Talcott SU, Chintharlapalli S, Li X, Safe S. The oncogenic microRNA-27a targets genes that regulate specificity protein transcription factors and the G2-M checkpoint in MDA-MB-231 breast cancer cells. Cancer Res. 2007 Nov 15;67(22):11001-11. [Medline: 18006846] [FREE Full Text] [doi: 10.1158/0008-5472.CAN-07-2416]

92. Tsuchiya Y, Nakajima M, Takagi S, Taniya T, Yokoi T. MicroRNA regulates the expression of human cytochrome P450 1B1. Cancer Res. 2006 Sep 15;66(18):9090-8. [Medline: 16982751] [FREE Full Text] [doi: 10.1158/0008-5472.CAN-06-1403]

93. Wu W, Lin Z, Zhuang Z, Liang X. Expression profile of mammalian microRNAs in endometrioid adenocarcinoma. Eur J Cancer Prev. 2009 Feb;18(1):50-5. [Medline: 19077565] [doi: 10.1097/CEJ.0b013e328305a07a]

94. Friedman JM, Liang G, Liu CC, Wolff EM, Tsai YC, Ye W, Zhou X, Jones PA. The putative tumor suppressor microRNA-101 modulates the cancer epigenome by repressing the polycomb group protein EZH2. Cancer Res. 2009 Mar 15;69(6):2623-9. Epub 2009 Mar 3. [Medline: 19258506] [FREE Full Text] [doi: 10.1158/0008-5472.CAN-08-3114]

95. Su H, Yang JR, Xu T, Huang J, Xu L, Yuan Y, Zhuang SM. MicroRNA-101, down-regulated in hepatocellular carcinoma, promotes apoptosis and suppresses tumorigenicity. Cancer Res. 2009 Feb 1;69(3):1135-42. Epub 2009 Jan 20. [Medline: 19155302] [FREE Full Text] [doi: 10.1158/0008-5472.CAN-08-2886]

96. Ivanovska I, Ball AS, Diaz RL, Magnus JF, Kibukawa M, Schelter JM, Kobayashi SV, Lim L, Burchard J, Jackson AL, Linsley PS, Cleary MA. MicroRNAs in the miR-106b family regulate p21/CDKN1A and promote cell cycle progression. Mol Cell Biol. 2008 Apr;28(7):2167-74. Epub 2008 Jan 22. [Medline: 18212054] [FREE Full Text] [doi: 10.1128/MCB.01977-07]

97. Petrocca F, Visone R, Onelli MR, Shah MH, Nicoloso MS, de Martino I, Iliopoulos D, Pilozzi E, Liu CG, Negrini M, Cavazzini L, Volinia S, Alder H, Ruco LP, Baldassarre G, Croce CM, Vecchione A. E2F1-regulated microRNAs impair TGFbeta-dependent cell-cycle arrest and apoptosis in gastric cancer. Cancer Cell. 2008 Mar;13(3):272-86. [Medline: 18328430] [doi: 10.1016/j.ccr.2008.02.013]

98. Scott GK, Goga A, Bhaumik D, Berger CE, Sullivan CS, Benz CC. Coordinate suppression of ERBB2 and ERBB3 by enforced expression of micro-RNA miR-125a or miR-125b. J Biol Chem. 2007 Jan 12;282(2):1479-86. Epub 2006 Nov 16. [Medline: 17110380] [FREE Full Text] [doi: 10.1074/jbc.M609383200] 
99. Mitomo S, Maesawa C, Ogasawara S, Iwaya T, Shibazaki M, Yashima-Abo A, Kotani K, Oikawa H, Sakurai E, Izutsu N, Kato K, Komatsu H, Ikeda K, Wakabayashi G, Masuda T. Downregulation of miR-138 is associated with overexpression of human telomerase reverse transcriptase protein in human anaplastic thyroid carcinoma cell lines. Cancer Sci. 2008 Feb;99(2):280-6. Epub 2008 Jan 14. [Medline: 18201269] [FREE Full Text] [doi: 10.1111/j.1349-7006.2007.00666.x ]

100. Ovcharenko D, Kelnar K, Johnson C, Leng N, Brown D. Genome-scale microRNA and small interfering RNA screens identify small RNA modulators of TRAIL-induced apoptosis pathway. Cancer Res. 2007 Nov 15;67(22):10782-8. [Medline: 18006822] [FREE Full Text] [doi: 10.1158/0008-5472.CAN-07-1484]

101.Bracken CP, Gregory PA, Kolesnikoff N, Bert AG, Wang J, Shannon MF, Goodall GJ. A double-negative feedback loop between ZEB1-SIP1 and the microRNA-200 family regulates epithelial-mesenchymal transition. Cancer Res. 2008 Oct 1;68(19):7846-54. [Medline: 18829540] [FREE Full Text] [doi: 10.1158/0008-5472.CAN-08-1942]

102.Lena AM, Shalom-Feuerstein R, Rivetti di Val Cervo P, Aberdam D, Knight RA, Melino G, Candi E. miR-203 represses ‘stemness' by repressing DeltaNp63. Cell Death Differ. 2008 Jul;15(7):1187-95. Epub 2008 May 16. [Medline: 18483491] [FREE Full Text] [doi: 10.1038/cdd.2008.69]

103.Zhao X, Yang L, Hu J, Ruan J. miR-138 might reverse multidrug resistance of leukemia cells. Leuk Res. 2010 Aug;34(8):1078-82. Epub 2009 Nov 6. [Medline: 19896708] [doi: 10.1016/j.leukres.2009.10.002]

104. Seike M, Goto A, Okano T, Bowman ED, Schetter AJ, Horikawa I, Mathe EA, Jen J, Yang P, Sugimura H, Gemma A, Kudoh S, Croce CM, Harris CC. MiR-21 is an EGFR-regulated anti-apoptotic factor in lung cancer in never-smokers. Proc Natl Acad Sci U S A. 2009 Jul 21;106(29):12085-90. Epub 2009 Jul 13. [Medline: 19597153] [FREE Full Text] [doi: 10.1073/pnas.0905234106]

105. Gaur A, Jewell DA, Liang Y, Ridzon D, Moore JH, Chen C, Ambros VR, Israel MA. Characterization of microRNA expression levels and their biological correlates in human cancer cell lines. Cancer Res. 2007 Mar 15;67(6):2456-68. [Medline: 17363563] [FREE Full Text] [doi: 10.1158/0008-5472.CAN-06-2698]

\section{To cite this article:}

Kolokythas A, Miloro M, Zhou X. Review of MicroRNA Deregulation in Oral Cancer. Part I.

J Oral Maxillofac Res 2011;2(2):e1

URL: http://www.ejomr.org/JOMR/archives/2011/2/e1/v2n2e1ht.pdf

doi: $10.5037 /$ jomr.2011.2201

Copyright (C) Kolokythas A, Miloro M, Zhou X. Accepted for publication in the JOURNAL OF ORAL \& MAXILLOFACIAL RESEARCH (http://www.ejomr.org/), 13 April 2011.

This is an open-access article, first published in the JOURNAL OF ORAL \& MAXILLOFACIAL RESEARCH, distributed under the terms of the Creative Commons Attribution-Noncommercial-No Derivative Works 3.0 Unported License, which permits unrestricted non-commercial use, distribution, and reproduction in any medium, provided the original work and is properly cited. The copyright, license information and link to the original publication on (http://www.ejomr.org/) must be included. 